\title{
Intangible cultural heritage elements in the visuals of the 6th grade Turkish textbook
}

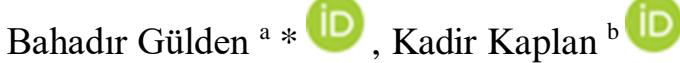 \\ ${ }^{a}$ Gazi University, Institute Of Educational Sciences, Ankara 06500, Turkey \\ ${ }^{b}$ Uşak University, Social Science Institute, Uşak, 64000, Turkey
}

\section{APA Citation:}

Gülden, B., \& Kaplan, K. (2019). Intangible cultural heritage elements in the visuals of the 6th grade Turkish textbook. Journal of Language and Linguistic Studies, 15(1), 291-306.

Submission Date:07/01/2019

Acceptance Date:07/02/2019

\begin{abstract}
The cultural elements are significant for native language teaching, so it is unavoidable that the Turkish textbooks include cultural elements. The aim of the research is to determine the presence of intangible cultural heritage elements in the visual materials (painting, photography etc.) in the secondary school 6th grade Turkish language textbook, and to examine the distribution of them according to their types. As a consequence of the study, 277 visual materials were determined as 125 photos, 98 digital drawings, 23 drawing, 15 illustrations, 4 banners, 3 table, 2 brochure, 2 graphics, and 2 sketches. Visuals that have intangible cultural heritage elements are found in photos which are Turkish coffee, Turkish delight, kemenche, horon, Mardin, Zeibek traditional, Palace of Ishak Pasha, tarhana soup, the making of tarhana, weaving, javelin game; digital drawings which are Nasreddin Hodja, Karagöz and shadow puppetry and drawings that are Chinese whispers, handkerchief game, kissing someone's hand. Gender apartheid or violent elements has not been detected in the visuals and they are appropriate for the grade level and text content. The visuals have properties of enhancing aesthetic sensitivity; however, the drawings are incomplete in terms of facial expression and emotion.
\end{abstract}

(C) 2019 JLLS and the Authors - Published by JLLS.

Keywords: Textbook; intangible cultural heritage elements; visual material

\section{Introduction}

Textbooks maintain its importance with respect to being the most used materials for teaching process. Like in many discipline, problems about the quality of textbooks are an important issue in the domain of Turkish learning. Aly1lmaz (2010) considers the problem of quality textbook among the current problems of learning Turkish in his study. The philosophy of the teaching program and every purpose of it has been incarnated on the textbooks as a kind of theory then turned into practice. Accordingly, the bound between the ability of reflect the curriculum into textbooks and reaching success in the aims of the program is directly proportional. In addition to this, the backbone of the learning activities are constituted by many elements notably textbooks and the texts, activities and visuals in the textbooks. The qualifications of these elements can affect the teaching a lesson process and the performance of the

\footnotetext{
${ }^{*}$ Corresponding author. Tel.: +0-000-000-0000

E-mail address: bahadirgulden@hotmail.com
} 
two most important elements of the education, the teacher and the student in both directions. The fact that the textbooks have such important and determinative functions necessitates the formation of the components in their content by examining them in many ways by different field experts. While preparing textbooks, it is necessary to focus on inter-field studies not content with the data of an area (İşeri, 2014, p. 81). Undoubtedly, one of the most important stages in the preparation of a qualified textbook is the creation of visuals. With the help of the visual elements, children can understand the abstract or complicated parts in the text easily (Şirin, 2000, p. 218-219). Although, at first glance, visuals are considered as concretized forms of text content in Turkish textbooks, it would be a serious mistake to limit their function in this way. The main features expected from the visuals are achieving the reader's attention to the book or the text which they belong to and contributing to the development of positive attitude towards it. The visuals are generally used in books in order to take advantage of the ornamental, complementary and interpretive functions of the text. (Oğuzkan, 2010, p. 372-373). In a more detailed classification for the functions of visuals in textbooks, concentration-provider, problem-creator, situational, creativity-encouraging, moving, critical, and priority-recency relationship-building attributes are mentioned (Köksal, 2011, p. 109). It's possible to improve the functionality of the textbook and reaching the target gain with the help of similar images. Being surrounded by books that have artistic value will help children to improve their liking and sensibility (Dilidüzgün, 2006, p. 112). From this point of view, it is necessary to expect individuals to develop their artistic sensibilities from textbooks and visuals of the books. Because it has seen that the visuals have significant effects on mental development when looking at the developmental characteristics of individuals. Individuals begin to perceive visuals from a young age, experience changes according to aesthetics and developmental periods. Therefore, visual designs should be created by paying attention to the aesthetic perception characteristics of the age group addressed to them when preparing textbooks. On the Parson's, Johnston's and Dunham's search results of children's aesthetic sense and the reaction, Experts like Kolberg and Piaget, revealed that individual aesthetic senses have various phases qualitatively and they are starting to shape in early ages (1978). Based on the findings of another study examining the judgments, attitudes and development of children about aesthetic perception, it has been confirmed that there is both the existence and developmental nature of the aesthetic awareness in children, it was advised that more attention should be paid to the studies about development of children's aesthetic perception (Helmund, 1987, p. 116). Another indicator that visuals have a serious role in understanding and explaining is the researches on image analysis and psychological painting tests. Although not very common in our country, in the US, Russia and Western countries, picture test is a significant method which provides the important clues about the psychology of the drawer (Halmatov, 2017). The result of these studies is that if the pictures can help to provide very important information when examined by the experts in explaining the communication point, the visuals prepared by the experts in obtaining the target objectives in terms of understanding and interpretation can give a more functional dimension to the textbooks.

Another dimension of the Turkish textbook is about culture. In addition language is the carrier of culture, since there are many relations between language and culture in many respects, while language acquisition processes are explained, culture is mentioned; while talking about cultural acquisition processes, mostly the native language is mentioned. In the Turkey Qualifications Framework, three of the eight competence areas include the aims about directly related to culture acquisition. It is mentioned that the communication of mother tongue is aimed in a suitable and creative language interaction in the social and cultural context in the four basic skill areas (MONE, 2018, p. 4). In the field of communication in foreign languages, it is emphasized that cultural accumulation is a determining factor in foreign language acquisition. At the last topic of sufficiency, a cultural function takes place and cultural fields like music, performing arts, literature and visuals arts are considered with priority and the importance 
of the individuals to express themselves in these areas is pointed out (MONE, 2018, p. 5). Curriculum of Turkey is prepared within the framework of the General Objectives and Basic Principles of Turkish National Education. This curriculum aims to give students certain qualifications. One of the qualifications is that recognizing and adopting aesthetic and artistic values through the works of Turkish and world culture and art. (MONE, 2018, s. 8). Based on this provision, learning program targets about native language learning should be in cooperation with cultural elements. For that reason, this is an unavoidable situation that including cultural elements and taking benefit from the culture in the duration of the language skills acquisitions on Turkish textbook (MONE, 2018, p. 8). The concept of culture has wide limits. Having such wide limits, bring this question to minds. "Which one will consider in the culture limit and which one will not?" For this reason, the cultural elements of the 6th grade textbook which is the subject of study in the research was detected by considering the cultural elements in the Intangible Cultural Heritage List and the images of these elements were examined. Intangible cultural heritage means; applications, representations, expressions, knowledge and abilities- and related tools, materials and cultural spaces- which are a part of cultural heritage definition of societies, groups and in some cases individuals (Oğuz, 2013, p. 63). In the "Definition" article, the protection of intangible cultural heritage contract, the term "protection" was used. This term was accepted by means that indooroutdoor education of intangible cultural heritage (Ministry of Culture and Tourism, 2003). Accordingly, "The List of Intangible Cultural Heritage" -which referred to cultural standard in the study, has connecting boundaries for educational activities.

\subsection{Research questions}

The aim of the study is to determine the presence of intangible cultural heritage elements in the visual materials (painting, photography, cartoon, etc.) of the secondary school 6th grade Turkish language textbook prepared by Ministry of National Education in 2018-2019 academic years. For this purpose, the following questions looked for answers:

1. What are the visual materials in the 6th-grade Turkish textbook prepared by MONE?

2. Are there any intangible cultural heritage elements in the visuals of the 6th-grade Turkish textbook prepared by MONE?

3. How is the distribution of the intangible cultural heritage elements in the 6th-grade Turkish textbook's visual materials? The search is limited by the 6th-grade Turkish textbook prepared by MONE which used in the primary textbook in the years of 2018-2019.

\section{Method}

A qualitative model was used in the study. In qualitative research, the qualification of a certain activity is explained. In this study, which was carried out in order to determine the existence of intangible cultural heritage elements in the visual materials (picture, photography, caricature etc.) and to analyze the distribution of these elements according to the types of visual materials, document analysis was conducted.

Document analysis is an analysis of material with information about the phenomenon or event intended to be investigated (Yıldırım \& Şimşek, 2008). In this context, Secondary School 6th Grade Turkish Language Textbook published in 2018 and prepared by Ministry of National Education Publications for 6 th grades was analyzed. 


\subsection{Data collection procedures}

The data collection process of the study was carried out in two stages. In the first phase, the visuals in the secondary school 6th grade Turkish language textbook dated 2018 and prepared for sixth grade students by Ministry of Education publication were examined based on the "Visual Material Types Detection Form". Also the types of visual materials were tried to identify.

In the second phase, the existence of intangible cultural heritage elements were investigated by using the "exist or not technique of Yıldırım \& Şimşek (2016) in the detected types of visual materials. In line with this technique, if there was an element about intangible cultural heritage, it was coded as "1". But when there was no evidence about intangible cultural heritage, it was coded as " 0 ". After the coding, data coded as " 1 " and " 0 " classified separately. As a result of the classification, visuals that have intangible cultural heritage elements were made suitable for content analysis.

\subsection{Data analysis}

In the analysis of data, data was interpreted according to predetermined themes with the help of descriptive analysis. According to Yıldırım and Şimşek (2008), in the descriptive analysis necessary framework was formed for analyzes and then data was processed based on the framework. In the next phase, the findings were identified and interpreted. In the study, formerly, visual materials in the 6thgrade Turkish textbook were reviewed one by one then the type of them detected. Afterwards, the coded data was tabulated. In the continuation of the study, visual materials with detected type were made with the visuals include UNESCO's "Humanity's Intangible Cultural Heritage List", "National Inventory of Intangible Cultural Heritage", 'Living Human Treasures' that could be classified within the "Position of The Folklore according to the ICH Contract". In this way, in the textbook, the visuals that contain both the official and the actual attributes of the ICH were detected. The encoded data were interpreted based on both the ICH attributes and the Criteria for the Evaluation of Pictures in the Textbook (Isseri, 2014).

To be sure about the reliability of the study, the data encoded by the researchers were presented to two field experts and the data were checked for compatibility with the researcher's codes. Using the formula of Huberman and Miles (1994) "Agreement / (Agreement+Disagreement)x100", 91 percent of the researcher and first field expert reached a consensus 95 percent of the researcher and the second field expert reached a consensus. The obtained ratios were considered reliable for research.

The codes that the researcher and field experts have difference of opinion re-discussed and placed on the appropriate type of visual material or the codes are completely excluded from evaluation For the purpose of internal validity; consistency of findings and their harmony with conceptual framework were checked. The process of the study was described in a detailed way to increase the external validity (transmissibility) of that. Main data kept for increasing the external validity of the study.

\section{Results}

In research, findings that obtained with the help of the data were clarified by taking the sequence of sub-problems into consideration.

Findings Related to the First Subproblem: Findings that obtained on the first sub-problem in the study has been shown in the first chart. Table 1. 
Table 1. Type of visual material

\begin{tabular}{cc}
\hline Photos & 125 \\
Digital Drawing & 98 \\
Drawing & 23 \\
Illustration & 15 \\
Banner & 4 \\
Map & 3 \\
Table & 3 \\
Brochure & 2 \\
Graphic & 2 \\
Sketch & 2 \\
TOTAL & 277 \\
\hline
\end{tabular}

In research, while looking at the visual materials in the secondary school 6th grade Turkish language textbook dated 2018 and prepared by MONE publications for the 6th grade, it had seemed 10 different visual materials that are; photographs, drawings, illustrations, banners, digital drawings, sketch, map, table and leaflet. In the texts and activities on the textbook, there are 277 visual materials in total. When the data in Table 1, which shows the distribution of these materials according to species, has been examined, it has been found that the most preferred visual material was the photograph $(n=125)$ by the textbook writers. It's followed by digital drawing (98), drawing (23), illustration (15), banner (4), table (3), map (3), leaflet (2), graphics (2) and sketch (2).

Findings Related to the Secondary: Findings that obtained for the second sub-problem in the study have shown in the second chart. 18 of the 277 visual materials that used in texts and activities in the textbook have shown the signs of intangible cultural heritage transmission. These 19 visual materials' distributions of types have shown in Table 2.

Table 2. Type of visual material

\begin{tabular}{ll}
\hline Photographs & 10 \\
Drawings & 5 \\
Digital drawings & 4 \\
TOTAL & 19 \\
\hline
\end{tabular}

Findings Related to the Third Subproblem: Findings obtained for the third sub-problem in the study, explained by interpreting the visuals. According to the data in Table 2, which shows the distribution of intangible cultural heritage according to species, it is determined that the most preferred visual material is the photograph $(n=10)$. The photograph is followed by digital drawing $(n=4)$ and drawing $(n=4)$ in terms of frequency of use. 


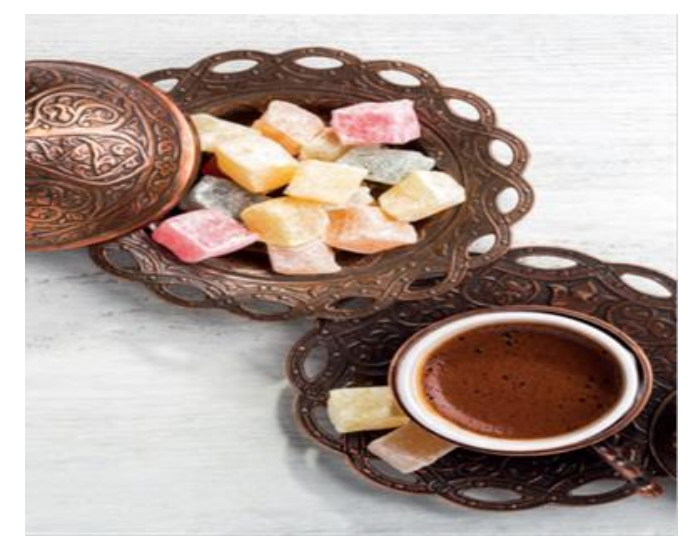

Visual 1

A photograph that represents the culture and tradition of Turkish coffee is used as the first visual. "The Culture and Tradition of Turkish Coffee" was able to get into "UNESCO's Representative List of İntangible Cultural Heritage of Humanity" with other 37 files in the year of 2013 because of meeting the technical requirements successfully. With its special baking technique and presentation, Turkish coffee is an irreplaceable part of our daily life with its effects on marriage rituals, traditional meetings and our food culture (Culture and Tourism Ministry, 2018). Also, In the ICH list, Turkish coffee tradition can be evaluated as one of the element of "Folk Cuisine" title which is in the culture field of "Information and Applications about Nature and Universe. Another cultural element that took place in the visual is Turkish delight. It was included in the National Inventory of Intangible Cultural Heritage in 2015 under the name of 'Delight Culture'.

When the visual number 1 is evaluated according to the picture evaluation criteria, it is seen that the colors in the photo are vivid and some of the primary colors are used. In addition to the vividness of the colors used, the coffee and copper embroidered coffee set, which is served with Turkish delight and coffee, is also a reflection of Turkish culture. In this respect, it can be said that the photograph increases the curiosity of the student. The photograph has aesthetic sensitivity-enhancing properties as well as being suitable for class level. There is no sign of sexual discrimination and violence.

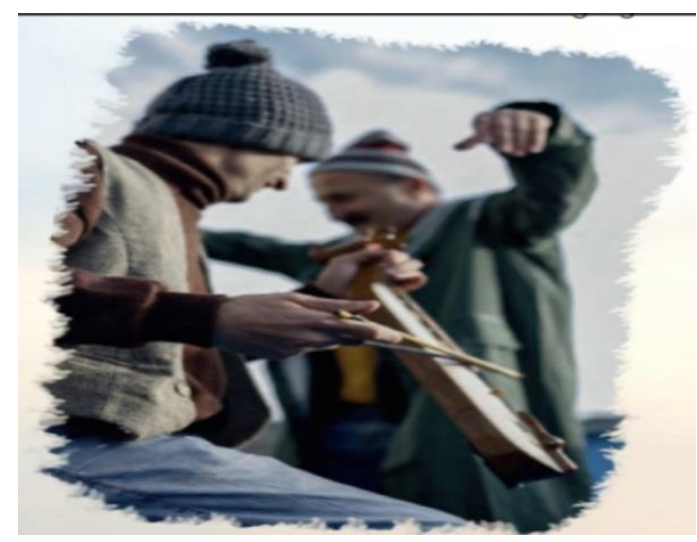

Visual 2

A photograph, showing "horon" the folk dance of the eastern Black Sea coastal region has been chosen as the second visual. Horon which was included in the National Inventory of ICH (01.0077), is in the field of Folk Dances (in the culture field of Performing Arts. It also shows kit (kemenche) because it's the main instrument for performing horon. In the context of ICH, like horon, kit is in the field of Folk Music (Stringed Folk Instruments) which is in the discipline of Performing Arts culture field. When 
visual number 2 is evaluated according to the drawing measures, it has seen that the vividness of colors is lower than the number 1 image and some of the main color has been used.

As a reflection of the Turkish culture, "horon" and the Black Sea People's clothing are drawing attention. In this respect, it can be said that photography will increase students' interest in the text. Photographs are proper for the grade level and they also increase aesthetic sense. There is no sign of sexual discrimination and violence.

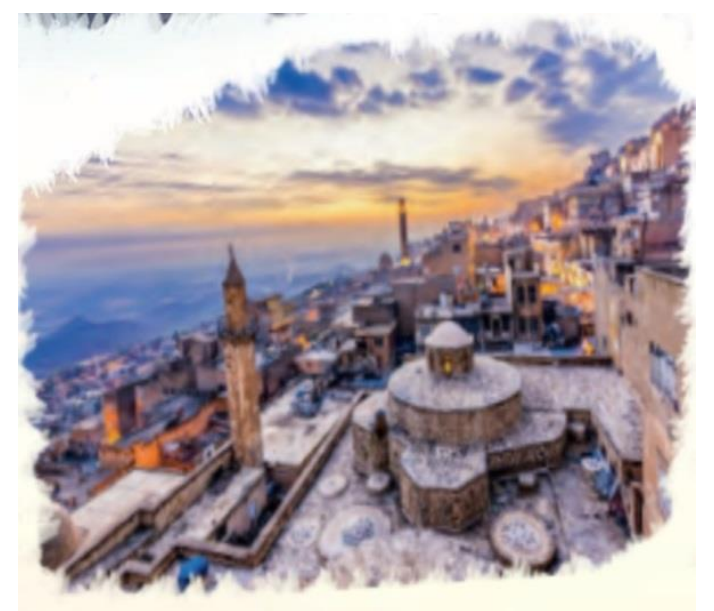

Visual 3

Third visual is a photograph that represents the architectural wealth of Mardin. Mardin is one of the 77 elements that have been approved to belong to Turkish culture in the UNESCO's Temporary List of World Heritage. This element was added to the list in the name of "Mardin Cultural Landscape Area" (Mardin) in 2000 [Ministry of Culture And Tourısm (MOCAT, 2018)]. When we assess the photo that was used according to photo picture assessment criteria, it is observed that the colors in the photo are vivid. A few of the primary colors have been used. Mardin has been on the Silk Road, it has been home for a number of civilizations and it has been certified as an archeological area by UNESCO. These facts are fairly important. With this aspect, this photograph will increase students' curiosity for the text and interest in the lesson.

This visual is appropriate for the grade level and for the text with its page layout, and it has features enhancing aesthetic sensitivity as well. There are not any elements that evoke sexual discrimination or violence.

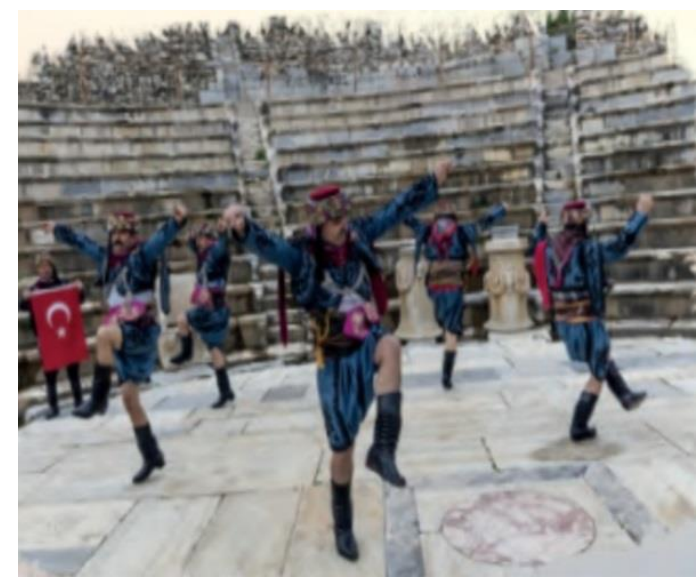

Visual 4 
Fourth visual is a photograph displaying. Zeibek, one of the Turkish folk dances. It was added to "ICH's National Inventory" (01.0060 Inventory Number) under the name of "Zeibek Tradition". Zeibek is in the subtitle of Folk Dances which is in the cultural sphere of Performance Arts. "Performance Arts" cultural site under the name of "Folk Dances". The photograph displays the people called "efe" playing zeibek dance. Besides, costume of Efes carry some cultural features as well.

The Handicrafts Tradition has features appropriate for "Apparel and Ornamentation" sphere (Ceremonial Apparel) which is in the cultural sphere of Performance Arts (Oğuz, 2013). When we assess the photo that was used according to photo picture assessment criteria, the colors in the photo are vivid and a few primary colors have been used if we want to mention about the brightness of the colors and about the primary color use. Zeibek is an important element belongs to Turkish culture. Therefore, Zeibek has been used in the course book and this is fairly important for both cultural transference and in-class motivation.

This visual is appropriate for the grade level and for the text with its page layout, and it has features enhancing aesthetic sensitivity as well. There are not any elements that evoke sexual discrimination or violence.

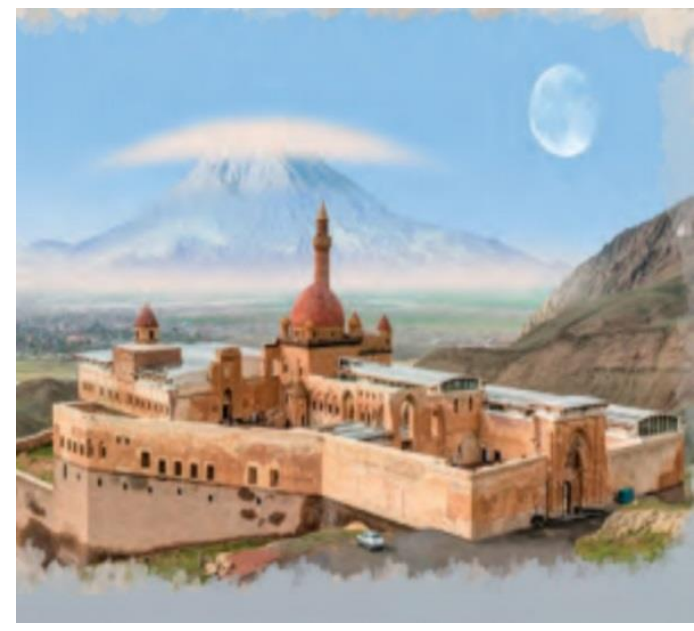

Visual 5

Ishak Pasha Palace, on which we can see West effect over Ottoman architeture, has been suggested to be added to UNESCO's World Heritage List because its stone carving and ornaments comprise the marks of a great variety of cultures from Persia to Anatolian Seljuk Empire, Georgia to Caucasia (MOCAT, 2018). Along with its features, Ishak Pasha Palace is an appropriate piece for being evaluated in the "Folk Architecture" cultural sphere which is included in the "Knowladge and Practices about Nature and Universe" cultural sphere.

Ishak Pasha Palace in Ağrı province draws the attention of both native and foreign tourists with its location a beauty. In the visual 5, a photograph of the aforementioned palace has been used. The photograph is at an acceptable level in terms of primary colors use and color vividness. Also, it has a great importance in terms of cultural transference and providing in-class motivation.

This visual is appropriate for the grade level and for the text with its page layout, and it has features enhancing aesthetic sensitivity as well. There are not any elements that evoke sexual discrimination or violence. 


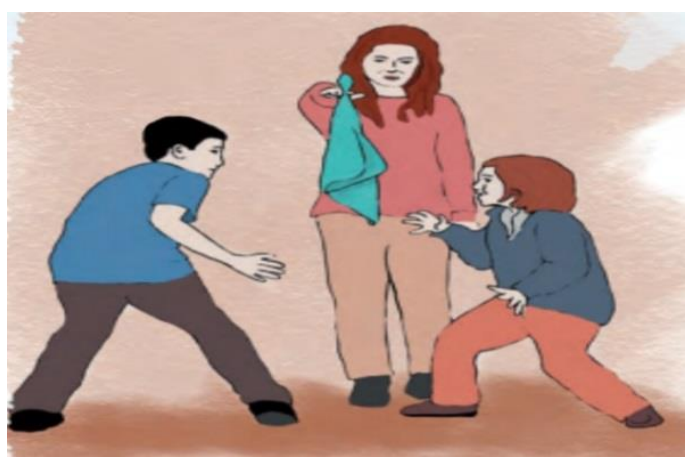

Visual 6

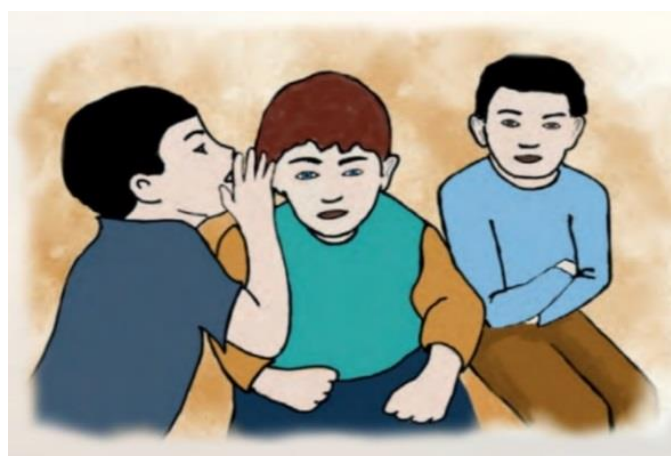

Visual 7

In the visual 6, drawing has been used as the type of the visual material. In the visual drawn by the committee, the handkerchief game - which is a culture bearer as well as it is an educative activity- has been illustrated, as a bearer of the culture. (Sümbüllü \& Altınışık, 2016). Being at an acceptable level in terms of primary colors use and color vividness, the drawing has a great importance for cultural transference.

This visual is appropriate for the grade level and for the text with its page layout, and it has features enhancing aesthetic sensitivity as well. There are not any elements that evoke sexual discrimination or violence.

In the visual 7, drawing method was used as the type of the visual material as well. In the visual drawn by the committee, Handkerchief Game was illustrated. Being at an acceptable level in terms of primary colors use and color vividness, the drawing has a great importance for cultural transference as the kids games are already culture bearers on their own. Handkerchief Game and Chinese Whispers are both elements which can be within the "Kids Games" category that is in the "Communal Practices, Rituals and Feasts" cultural sphere. It can be state that the visuals, which were created by drawing and which represent the handkerchief game and Chinese Whispers, have been drawn through simple designing method. In that, it is supposed that more details need to be included in these visuals in order to enhance the functionality of the pictures. Especially, there are not details about facial expressions of the illustrated individuals so we cannot clearly express that this illustrated cultural element is interesting and enjoyable. In the visual, while we suppose to see joy in the facial expressions of the children playing hankerchief, the emotion we easily infer from the faces of them is nervousness. Moreover, the game moderator who is holding the handkerchief seems to be unhappy due to the fact that he is playing that game. Also, in the visual 7, it is hard to comprehend that the children feel joyful and excited in that game.

This visual is appropriate for the grade level and for the text with its page layout, and it has features enhancing aesthetic sensitivity as well. There are not any elements that evoke sexual discrimination or violence. 


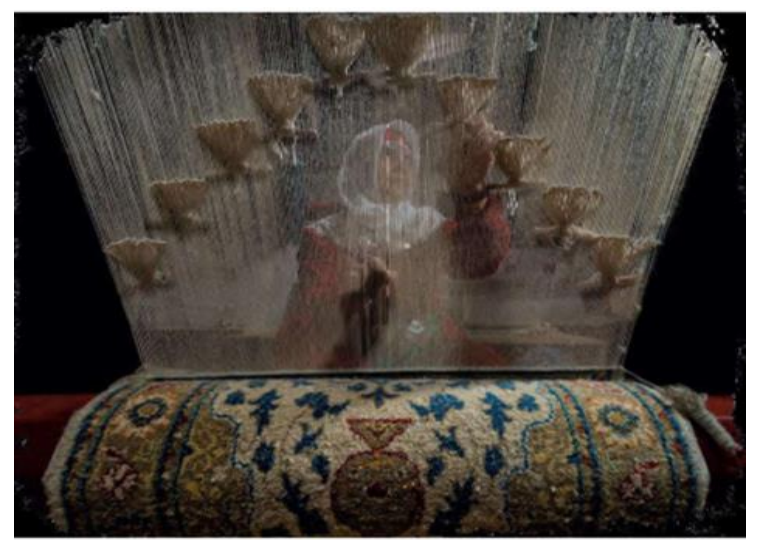

Visual 8

In the visual 8, a photograph was used as the type of visual material. In the photograph, "weaving" that is one of the traditional folk arts and an important element of Turkish culture was used an important element of Turkish culture- was used. Weaving tradition is seen in the "National Inventory of Intangible Cultural Heritage List" with two inventory number and under two titles: "Rug Weaving Tradition (inventory number: 01.0042)" and "Carpet Weaving Tradition (01.0035)" (MOCAT, 2018). In the visual in which a Turkish woman who was photographed while weaving a rug, the use of primary colors and vividness of the colors are at an acceptable level. Photograph has a great importance for cultural transference and in-class motivation.

This visual is appropriate for the grade level and for the text with its page layout, and it has features enhancing aesthetic sensitivity as well. There are not any elements that evoke sexual discrimination or violence.

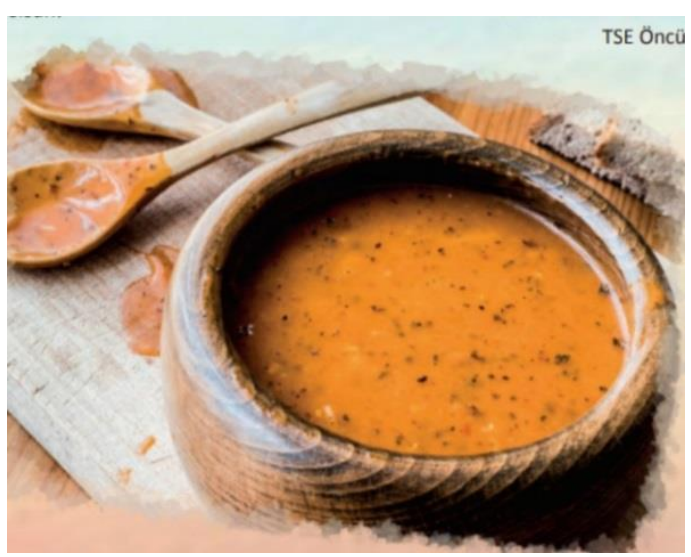

Visual 9

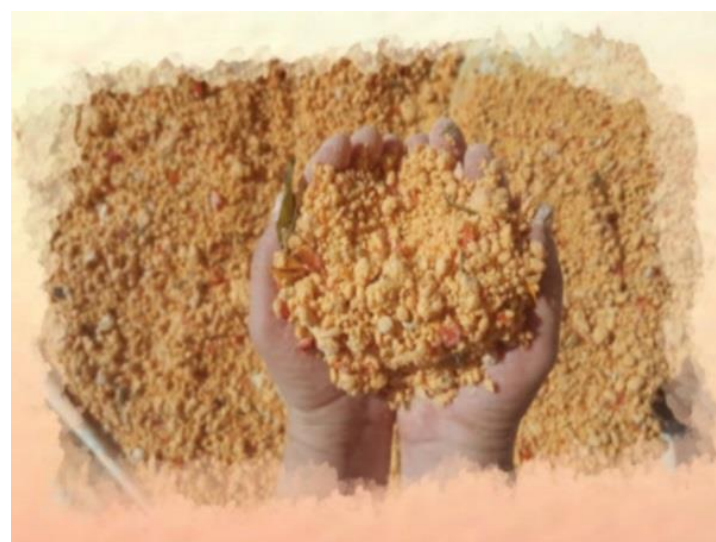

Visual 10

In the visuals 9 and 10, photograph method was used as the type of visual material. Tarhana, which has an important place in the Turkish nutrition culture (Özçelik \& Özdoğan, 2007), was used.

The visuals, which are displaying preparation process of tarhana and cooked tarhana soup, are at an acceptable level in terms of primary colors use and color vividness. Photograph has a great importance for cultural transference and in-class motivation. The tradition of making tarhana and tarhana soup take part in "folk cuisine" which is a sub-title of the "Knowledge and Practices Culture area related to Nature and the Universe.'

This visual is appropriate for the grade level and for the text with its page layout, and it has features enhancing aesthetic sensitivity as well. There are not any elements that evoke sexual discrimination or violence. 


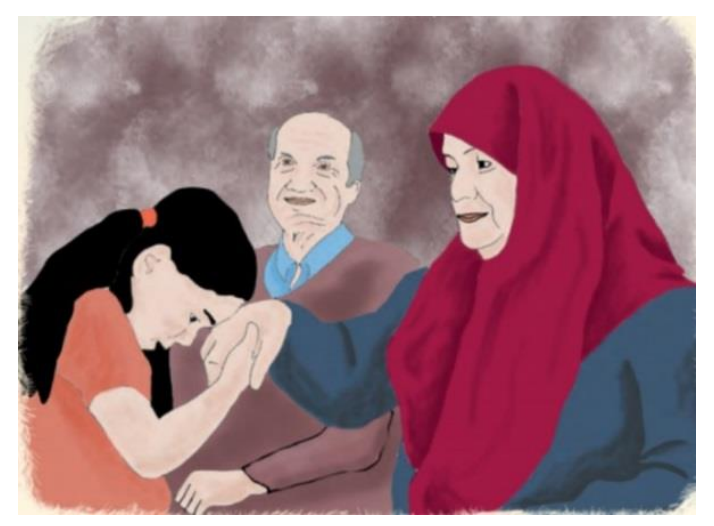

Visual 11

In the visual 11, drawing method has been used as the type of visual material. It displays hand-kissing tradition - one of the Turkish traditions- which are a sign of respect to the elders. It can be stated that this is an appropriate element for "Traditions" which is under the subtitle "Public Law" of "Communal Practices, Rituals and Feasts" cultural sphere in The Intangible Cultural Heritage List". This drawing is at an acceptable level in terms of primary colors use and color vividness, however it is seems in the picture that the person whose hand is being kissed is not pleased even at that moment she is respected. Like the other drawings, this one is not satisfactory in terms of facial expressions and emotions it needs to display. This drawing is fairly important for cultural transference.

This visual is appropriate for the grade level and for the text with its page layout, and it has features enhancing aesthetic sensitivity as well. There are not any elements that evoke sexual discrimination or violence.

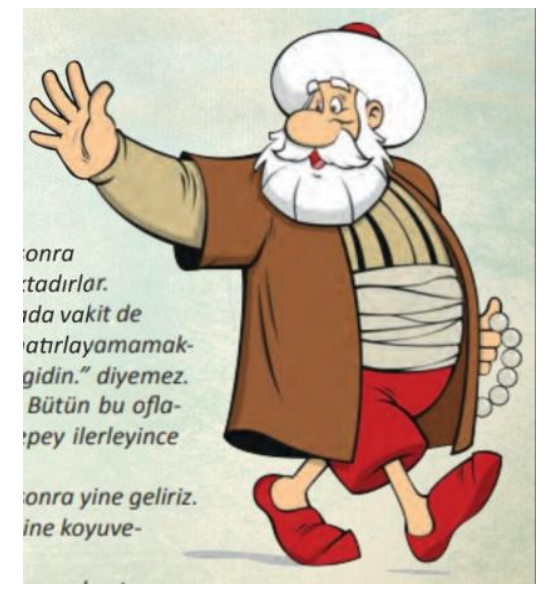

Visual 12

In the visual 12, drawing method has been used. Nasreddin Hodja - the humour character known world wide - was used in this digital drawing. It is possible to find traces of Nasreddin Hodja in literature, art and folk beliefs (Şanl1, 2014) and he is an important representative of Turkish humour. Even though we can only see jokes in Oral Traditions and Narrations cultural sphere in ICH, these jokes could manage to get in the Intangible Cultural Heritage National Inventory as "The Tradition of Telling Nasreddin Hodja Jokes". First of all, telling Nasreddin Hodja jokes is a cultural element on its own and it is appropriate for the fact of protecting a living tradition -which is one the basic standart of ICH agreement -by transferring it from generation to generation. This digital drawing is at an acceptable level in terms of primary colors use and color vividness. This digital drawing has a great importance for cultural 
transference and in-class motivation. Place in ICH as "Verbal Traditions and Verbal Lectures", they also achieved to take place in the "National Inventory of Intangible Cultural Heritage List" with the title of "Tradition of Telling Nasreddin Hodja Jokes".

This visual is appropriate for the grade level and for the text with its page layout, and it has features enhancing aesthetic sensitivity as well. There are not any elements that evoke sexual discrimination or violence.

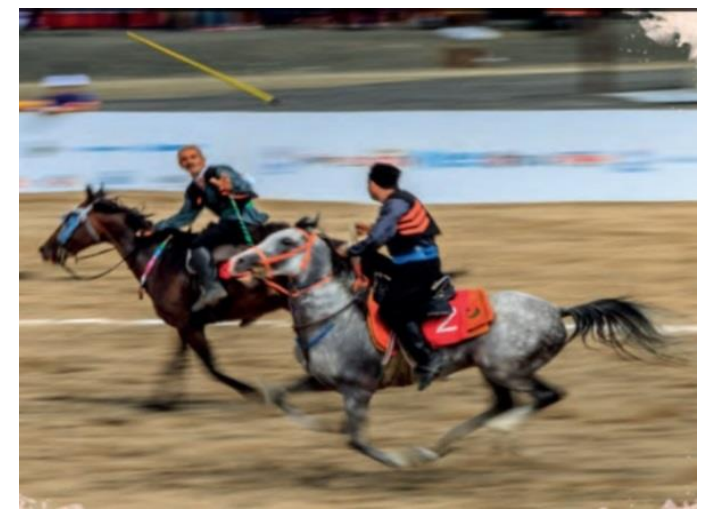

Visual 13

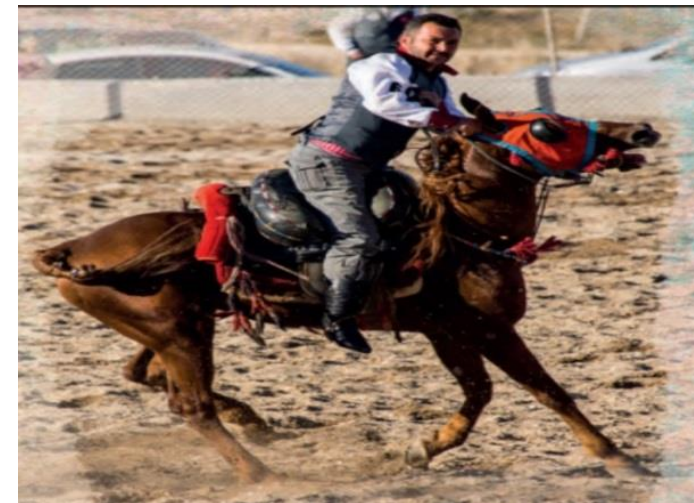

Visual 14

In the visual 13 and 14, the photograph has been used as the type of visual material. In the photograph, one of the traditional Turkish sports "javelin" which is known as an ancestor sport was preferred. Being one of our precious and oldest ancestor games; javelin has been played for years by using a heavy and thick javelin and it is an open space game (Koçan, 2007). It is in the "Element List of National Intangible Cultural Heritage Inventory". And it is one of our cultural values which is in the "Public Sports" cultural sphere of "Communal Practices, Rituals and Feasts".

The photographs are at an acceptable level in terms of primary colors use and color vividness. In photographs, the use of main colors and brightness of them is at a sufficient level. They have a great importance for cultural transference and in-class motivation. And it is obvious that the visuals used help us make sense of the text.

This visual is appropriate for the grade level and for the text with its page layout, and it has features enhancing aesthetic sensitivity as well. There are not any elements that evoke sexual discrimination or violence.

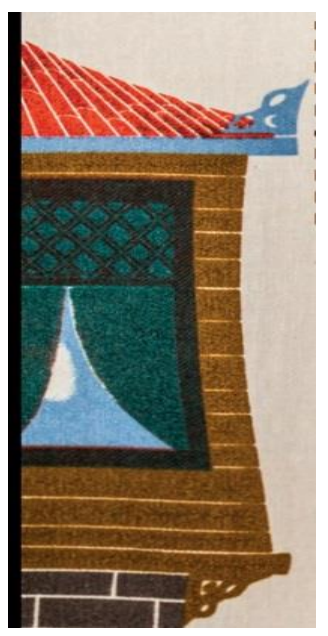

Visual 15

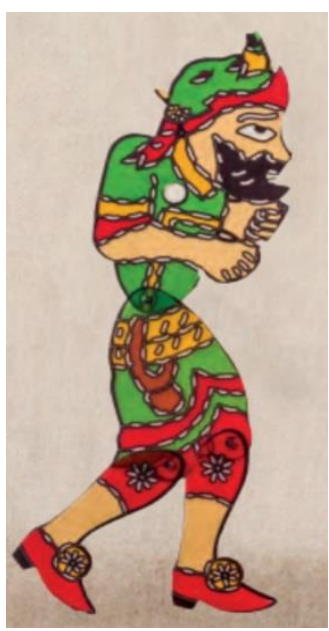

Visual 16

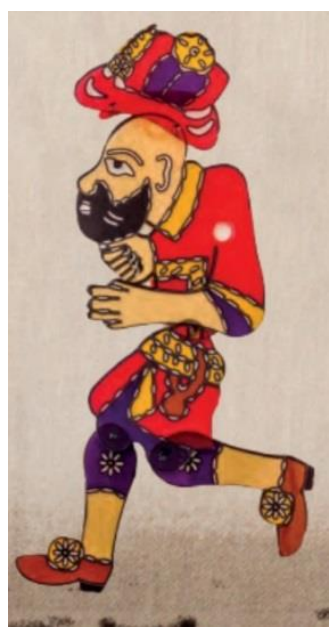

Visual 17

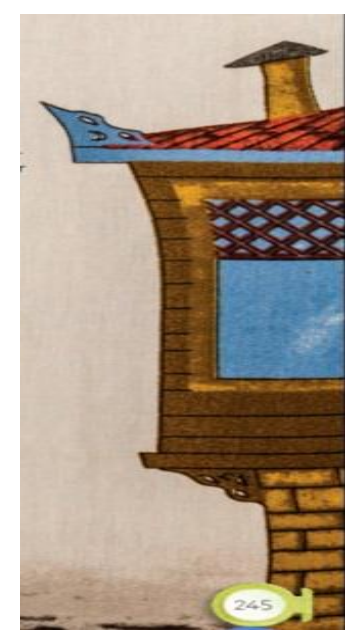

Visual 18 
Digital drawing was used as the type of visual material in the 15th, 16th, 17th and 18th visuals. Hacivat, Karagöz -characters of the Turkish shadow puppetry- and their house that is one of the settings o shadow puppetry has been used in these digital drawings. Karagöz is under the title "Folk Theater" which is in the Performance Arts cultural sphere. Apart from its being in the Natioanal Inventory Elements List of Intangible Cultural Heritage, Karagöz was accepted at the 4. Intergovernmental Committee Meeting of Protecting Intangible Cultural Heritage in 2009 and became entitled to be added to the Representative List of Intangible Cultural Heritage of Humanity, so it was officially registered that Karagöz a value that is globally qualified (MOCAT, 2011). These digital drawings are at an acceptable level in terms of primary colors use and color vividness. Digital drawings displaying shadow puppetry that is regarded as the branch of the traditional Turkish theater (Tuncel, 2013) have a great importance for cultural transference and in-class motivation.

This visual is appropriate for the grade level and for the text with its page layout, and it has features enhancing aesthetic sensitivity as well. There are not any elements that evoke sexual discrimination or violence.

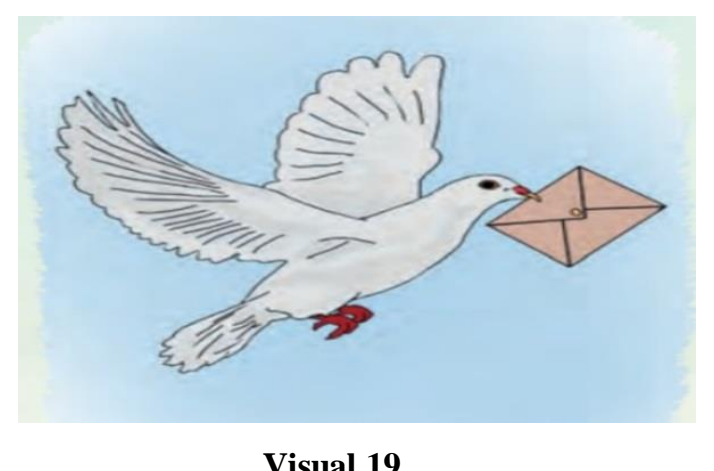

In the visual 19, there is a visual about using animals which is one of the "Public Communication Techniques" that is in the "Knowledge and Practices About Nature" cultural sphere. Related to theme of Science and Technology, the last stage of communication and early communication techniques were mentioned in the text. That is why the technique of communication by using pigeons has been included in the visuals. Being a sample of digital drawing, this visual is appropriate for the grade level and for the text with its page layout, and it has features enhancing aesthetic sensitivity as well. There are not any elements that evoke sexual discrimination or violence. These digital drawings are at an acceptable level in terms of primary colors use and color vividness.

\section{Discussion}

ICH Agreement aims to prevent the demolition of the cultural wealth that have been able to survive for thousands of years by being passed down as a result of nations' adoption a certain type of culture because of the financial and technologic power of a few dominant cultures throughout the world (Oğuz, 2013; p. 8). One of the main steps of this struggle for survival is to transfer the compiled cultural wealth to the new generations. So, it is important to include the cultural elements thematically in the Turkish course books as well as it is important for students to learn more about their cultures. The students acquaint themselves with their own cultures and maintain them; and we can consider that these are among the steps forming the main philosophy of UNESCO's Intangible Cultural Heritage Agreement. Therefore, it is one of the responsibilities of Turkey - as a party of this agreement- as well as others to include The Intangible Cultural Heritage in the educational activities. For this reason, it will be necessary and useful to increase the type and the number of the cultural elements, which can be coherently 
associated with Turkish lesson themes, in the course books. So, it will be possible for students to get informed about many cultural elements through the Turkish lesson. At the same time, we will contribute more to the aim of protecting and maintaining the UNESCO's Intangible Cultural Heritage through education as we make the cultural elements survive.

\section{Conclusions}

In the Turkish textbook, there are totally 277 visuals that have been detected. 125 of them are photos, 98 of them are digital drawings, 23 of them are drawing, 15 of them are illustration, 4 of them are banners, 3 of them are maps, 3 of them are table, 2 of them are brochures, 2 of them are graphics, 2 of them are sketches in the visuals. Intangible cultural heritage elements have been found in some kinds of visuals including photos, drawings and digital drawings. 10 of the visuals in the intangible cultural heritage elements are photos. Among these, there are some visuals detected which are related to Turkish coffee, Turkish delight, kemenche, horon, Mardin (Cultural Landscape Area), The Zeibek Tradition, Ishak Pasha Palace, weaving, tarhana soup, tarhana making, and javelin. In the visuals of drawing; some elements have been detected which reflect the handkerchief game, the Chinese whisper, the tradition of kissing hands (as respect for elderly people). In the visuals of digital drawing, some other elements belong to Nasreddin Hodja, Karagöz and shadow puppetry have been detected.

There are not any detected elements which set sexual discrimination or bring violence into mind in these visuals. Moreover, the visuals are suitable for the grade level and the texts. The visuals also have some features enhancing the aesthetic sensibility, but the drawings are insufficient in terms of facial expression and emotion.

Upon looking through the cultural elements used in the course book, it is possible to say that visuals, which are appropriate for the interests and the development features of students, have been used. In the visuals, no findings were found in the List of Living Human Treasures. While Turkish coffee and Turkish delight, horon and kemenche, Mardin, zeibek, İshak Pasha Palace, handkerchief game, Chinese whispers, weaving and tarhana soup are of the visuals that have been found in "National Culture" theme, cirit (javelin), Nasreddin Hodja and his jokes are of the visuals that are in the "Health and Sport" theme. The element of public communication techniques (letter, use of animal) ways are in the Science and Technology theme. Karagöz, Nasreddin Hodja and his jokes are found in the "Individual and Society" theme. Visuals in the themes of Reading Culture, The War of Independence and Atatürk, Virtues, Nature and Globe cannot be directly associated with "The Representative List of Intangible Cultural Heritage of Humanity", "The National Inventory of Intangible Cultural Heritage" or "Living Human Treasures" because there is no directly relationship between them.

\section{References}

Alyılmaz, C. (2010). Problems of Teaching Turkish. Turkish Studies (Volume 5/3 Summer 2010), 728-749.

Batur (Eds.), Z., Ceylan, S., Duru, K., Erkek, G., \& Pastutmaz, M. (2018). Secondary School 6th Grade Turkish Language Textbook (Eds). Ankara: MONE State Books.

Dilidüzgün, S. (2006). The Contribution of Children's Books to Children's Art Education. II. National Child and Youth Literature Symposium, 111-115.

Halmatov, S. (2017). Children's Painting Analysis and Psychological Painting Tests. Ankara: Pegem Academy Publishing. 
Helmund, J. (1987). Children's Aesthetic Perception: A Developmental Study of Judgements and Attitudes Concerning the Drawings and Paintings of Children. Boston.

İşeri, K. (2014). Pictures in Turkish Textbooks. T. D. Analyzes within, Hakan Ülper (Eds.) (3. b., s. 8190). Ankara: Pegem Academy.

Koçan, N. (2007). The Adaptation of javelin which is one of Traditional Sports to the Present with the Purpose of Recreation. Journal of Sports Management and Information Technology, 2(1), 31-39.

Köksal, H., \& Küçükahmet, L. (2011). Subject Area Textbook Review Guide. Ankara: Nobel Publications.

Ministry of Culture And Tourssm. (2003, 10 17). Convention on the Protection of Intangible Cultural Heritage. retrieved from http://teftis.kulturturizm.gov.tr/TR-50543/somut-olmayan-kulturelmirasin-korunmasi-sozlesmesi.html.

Ministry of Culture And Tourssm. (2011). General Directorate of Research and Education. UNESCO Representative List of the Intangible Cultural Heritage of Humanity ve List of Intangible Cultural Heritage that requires urgent protection: retrieved from http://aregem.kulturturizm.gov.tr/TR12282/unesco-somut-olmayan-kulturel-miras-vi-hukumetlerarasi-.html.

Ministry of Culture And Tourısm. (2018, 10 07). General Directorate of Research and Education. National Inventory of Intangible Cultural Heritage: retrieved from http://aregem.kulturturizm.gov.tr/TR-159257/somut-olmayan-kulturel-miras-ulusal-envanteri.html.

Ministry of Culture And Tourısm. (2018, 10 09). CULTURAL ASSETS AND MUSEUMS GENERAL DIRECTORATE. World Heritage Temporary List: retrieved from http://www.kulturvarliklari.gov.tr/TR-44395/dunya-miras-gecici-listesi.html.

Ministry of Culture And Tourism. (2018, 10 10).General Directorate of Cultural Heritage and Museums. Ishakpasa Palace (A $\breve{g r l})$ :retrieved from http://www.kulturvarliklari.gov.tr/TR44406/ishakpasa-sarayi-agri.html.

Ministry of Culture And Tourssm. (2018, 10 09). Turkish Coffee Culture and Tradition UNESCO Representation List of the Intangible Cultural Heritage of Humanity. TURKISH COFFEE'S UNESCO JOURNEY: retrieved from http://aregem.kulturturizm.gov.tr/TR-76265/turk-kahvesikulturu-ve-gelenegi-unesco-insanligin-somu-.html.

MONE. (2018). Turkish Language Teaching Program. Ankara.

Oğuz, M. Ö. (2013). What is Intangible Cultural Heritage? Ankara: Traditional Publishing.

Oğuzkan, A. F. (2010). Children's Literature. Ankara: Anı Publishing.

Özçelik, A. Ö., \& Özdoğan, Y. (2007). The Place and Importance of Tarhana in Turkish Nutrition Culture. 38. Icanas Uluslararast Asya ve Kuzey Afrika Congress of Studies (s. 1025-1040). Ankara: Atatürk High Council of Culture, Language and History.

Parsons, M. J. (1978). Developmental Stages in Children's Aesthetic Responses. Journal of Aesthetic Education 12(1), 83-104.

Sümbüllü, Y. Z., \& Altınışı, M. (2016). Importance of Traditional Children's Games for Values Education. ETÜ, Journal of Social Sciences Institute, 1(2), 73-85.

Şanl1, İ. (2014). Cultural Elements in Nasreddin Hodja Anecdotes. Eskişehir Osmangazi University Journal of Social Sciences, 10(1), 261-271. 
Şirin, M. R. (2000). Children's Literature in 99 Questions. İstanbul: Children's Foundation Publications.

Tavkul, U. (1993). Historical Turkish Men's Clothing. National Folklore (19), 40-45.

Tuncel, U. (2013). Axel Olrik'in Halk Anlatılarının Epik Yasaları Bağlamında Ağalık Adlı Karagöz Oyunu Çözümlemesi. Journal of Turkish Language and Literature, 48, 204-240.

Ülper (Eds.), H., Arı, G., Çetinkaya, G., \& Güneyli, A. (2014). Turkish Textbook Analysis. Ankara: Pegem Academy Publications.

\section{6.sınıf Türkçe ders kitabındaki görsellerde somut olmayan kültürel miras ögeleri}

\section{$\ddot{O} \mathbf{z}$}

Kültürel ögeler ana dilin öğretiminde çok önemli olduğu için Türkçe ders kitaplarında kültürel öğelere yer verilmesi kaçınılmaz bir durumdur. Bu araştırma Ortaokul Türkçe 6 Ders Kitabı'nda yer alan görsel materyallerde (resim, fotoğraf, karikatür vb.) somut olmayan kültürel miras ögelerinin varlığını tespit etmek ve bu ögelerin görsel materyal türlerine göre dağılımını incelemek amacıyla yapılmıştır İnceleme sonucunda 125 'i fotoğraf, 98 'i dijital çizim, 23'ü çizim, 15'i illüstrasyon, 4'ü afiş, 3'ü harita, 3'ü tablo, 2'si broşür, 2'si grafik, 2'si kroki olmak üzere toplam 277 görsel materyal tespit edilmiştir. Somut olmayan kültürel miras unsurlarına ise fotoğraf, dijital çizim ve çizim türlerindeki görsellerde rastlanmıştır. Somut olmayan kültürel miras unsurlarını barındıran görsellerden 10’u fotoğraftır. Bunların içinde Türk kahvesi, Türk lokumu, kemençe ve horon, Mardin (Kültürel Peyzaj Alanı), Zeybeklik Geleneği, İshak Paşa Sarayı, dokumacılık, tarhana çorbası, tarhana yapımı, cirit oyununa ait görseller tespit edilmiştir. Çizim türündeki görsellerde ise mendil kapmaca, kulaktan kulağa, el öpme geleneğini (büyüklere sayg1) yansıtan unsurlar tespit edilmiştir. Dijital çizim kapsamına giren görsellerde ise Nasreddin Hoca, Karagöz ve gölge oyununa ait diğer unsurlar tespit edilmiştir. Görsellerin hiçbirinde cinsiyet ayrımcılı̆̆ oluşturacak ya da şiddet olaylarını çağrıştıracak bir unsur tespit edilememiştir. Bununla birlikte görseller, sınıf seviyesine ve metin içeriklerine uygundur. Görseller, aynı zamanda estetik duyarlılı̆̆ artırıcı özellikler de taşımaktadır. ancak çizimlerin yüz ifadesi ve duygu bakımından eksik olduğu görülmüştür.

Anahtar sözcükler: Ders kitabı; somut olmayan kültürel miras ögeleri; görsel materyal

\section{AUTHOR BIODATA}

Bahadır Gülden is a PhD student in the Department of Turkish Language Teaching at Gazi University. . He has been working as a Turkish teacher at Republic of Turkey Ministry of National Education (MONE) since 2007. He works on the acquisition of four basic language skills, cultural transfer in mother tongue, curriculum programs and textbooks.

Kadir Kaplan is a PhD student at the Department of Turkish Language Teaching at Uşak University. He has been working as a Turkish teacher at Republic of Turkey Ministry of National Education (MONE) since 2007. He works on the acquisition of four basic language skills, cultural transfer in mother tongue, curriculum programs and textbooks. 